\title{
Transfers and Distortions Along CEEC Food Supply Chains
}

\author{
Matthew Gorton, Allan Buckwell and Sophia Davidova
}

\section{INTRODUCTION}

Since the downfall of communism, Central and East European Countries (CEECs) have pursued an array of agricultural and food policies. These have included price controls at farm, processing and retail levels, margin and profit limitations, credit and budgetary subsidies to farmers and assorted trade controls. Moreover, policies employed have varied considerably between countries and over the period of transition and have been applied to underdeveloped (noncompetitive markets). Many of the policies would appear to be inconsistent with each other and at first glance it is difficult to characterise the degree of protection (taxation) afforded to farmers and the implications for final consumers.

This paper aims to present an overview of the nature of transfers along, and levels of distortion within, five key agro-food chains in six CEECs. In undertaking this research, four key questions are apparent. First, is it possible to compare margins and transfers along agro-food supply chains at an international level? What problems emerge in making cross-national comparisons? Second, who are the main beneficiaries of transfers along supply chains and how does this vary between countries? This leads on to the question as to what are the size and causes of these distortions and finally, what methods may be employed to understand and evaluate the causes of these distortions?

In attempting to deal with the first question, measuring transfers along food supply chains on a cross-national basis, a methodology developed by Ivanova et al., (1995) and discussed by Swinnen (1998), is adopted. The approach is applied to five 
supply chains: grain / flour / bread, pork, beef, chicken and milk. These chains were chosen because of their importance within household purchases and the level of support afforded to these products in the EU and CEECs. The six CEECs covered in the analysis are: Bulgaria, Czech Republic, Hungary, Poland, Romania and Slovenia. These countries were chosen to give a mix of first and second wave candidates for EU accession.

This paper is organised into seven parts. Section two introduces the methodology employed in the study. Part three presents an overview of the results of the transfer analysis for the six countries with sections four to six covering the results at farm, processing and retail / consumer levels respectively, in greater detail. The final section draws out the main conclusions from this analysis and the degree to which support and protection in CEEC food supply chains has varied geographically and temporally.

\section{METHODOLOGY FOR THE ESTIMATION OF TRANSFERS}

The methodology for measuring transfers is based on calculating Producer Subsidy Equivalents (PSEs) and Consumer Level Equivalents (CSEs) for each stage of the agro-food chain (farm level, first stage processors, second stage processors, retailers, and final consumers). PSEs are widely used as a measure of agricultural support and this approach is extended to include subsequent stages of the food chain. At the farm level, PSEs can be defined as the value of monetary transfers from consumers of agricultural products and from taxpayers to producers, resulting from a given set of agricultural and trade policies in a given year. CSEs, accordingly, measure the value of monetary transfers from domestic consumers to producers and from taxpayers to consumers resulting from a given set of agricultural and trade policies and market structures in a given year. The essence of the calculation is a comparison of domestic and international market prices at each stage of the food chain.

At the farm level the total PSE for a particular commodity can be stated as:

$$
\mathrm{PSE}_{\mathrm{F}}=\mathrm{Q}_{\mathrm{F}}\left(\mathrm{P}_{\mathrm{fd}}-\mathrm{P}_{\mathrm{fw}}\right)+(\mathrm{D}+\mathrm{I})-\mathrm{L}
$$


Where $\mathrm{Q}_{\mathrm{F}}$ is the domestic farm level of production of the commodity; $\mathrm{P}_{\mathrm{fd}}$ is the domestic farm gate price; $\mathrm{P}_{\mathrm{fw}}$ is the world reference price (adjusted as detailed below); $\mathrm{D}$ refers to direct payments to farmers; L represents the levies and agricultural taxes for producers; and I refers to indirect payments to farmers and all other state-financed support. The direct and indirect support measures, $(\mathrm{D}+\mathrm{I})$, within OECD calculations are divided into four categories: direct payments, public spending which reduces input costs, general services, and a miscellaneous category of other indirect support.

If the total PSE is zero, producers are operating at world market prices with neither support nor protection and in an open and competitive market. If PSEs are positive, then farmers are being supported - they are either receiving a price above free market levels for their output, gaining from some market imperfection, or benefiting from government subsidies. If the total PSE is negative, farmers are effectively being taxed. This may be due to farmers: (i) supplying their output at prices below world market levels, (ii) being taxed either as a result of agricultural or trade policies, and/or (iii) market imperfections exist which act against their interests.

In estimating the PSEs for livestock commodities at the farm level, formula [1] is refined to include a farm feed adjustment. Livestock farmers may also gain (or lose) if the prices of the feed inputs they use are below (above) world market levels:

$$
\mathrm{PSE}^{*}=\mathrm{PSE}-\mathrm{x}_{\mathrm{i}}\left(\mathrm{P}_{\mathrm{id}}-\mathrm{P}_{\mathrm{iw}}\right)
$$

Here $\mathrm{x}_{\mathrm{i}}$ refers to the quantity of feed used in the production of the livestock commodity and PSE* refers to the input adjusted PSE. $\mathrm{P}_{\mathrm{id}}$ is the domestic price of feed input ${ }_{\mathrm{i}}$ and $\mathrm{P}_{\mathrm{iw}}$ is the world price of that input. If feeds are 'taxed' $\left(\mathrm{P}_{\mathrm{id}}>\mathrm{P}_{\mathrm{iw}}\right)$, it follows that PSE* $<$ PSE, and if feed prices are 'subsidised' $\left(\mathrm{P}_{\mathrm{id}}<\mathrm{P}_{\mathrm{iw}}\right)$, then PSE* $>$ PSE.

This study expands the farm level coverage by applying the methodology to downstream sectors (processing, retail and final consumer). Figure 1 indicates the transfers involved in estimating PSEs and CSEs at each stage of the food chain. 


\section{Figure 1: The Estimation of PSEs at each stage of the food chain}

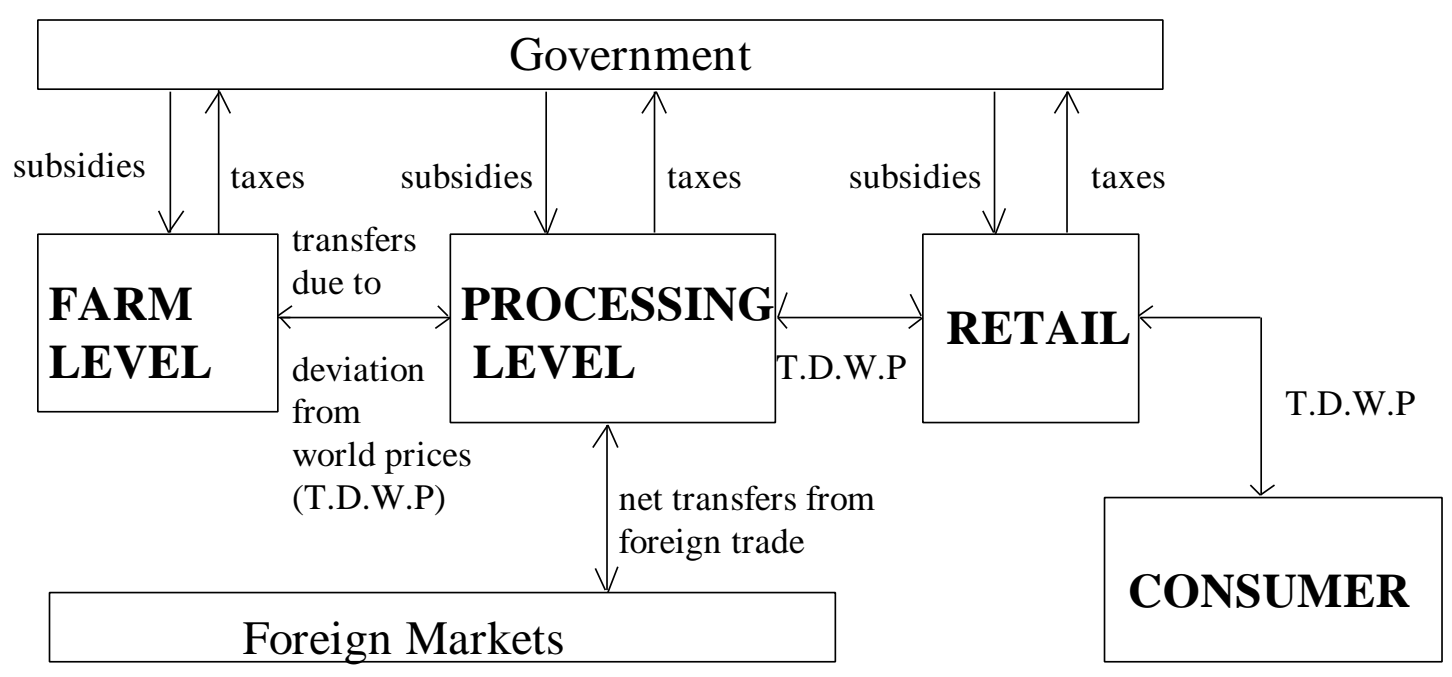

At the processor level, the total PSE (TPSE) or net transfer can be defined as:

$$
\mathrm{TPSE}_{\mathrm{p}}=\mathrm{PSE}_{\mathrm{p}}+\mathrm{Q}_{\mathrm{p}} \mathrm{k}_{1} \mathrm{CSE}_{\mathrm{uf}}
$$

where $\mathrm{PSE}_{\mathrm{p}}$ is the processor level PSE; $\mathrm{Q}_{\mathrm{p}}$ the quantity processed; $\mathrm{k}_{1}$ the technical coefficient for converting the farm level good into the processed product; and $\mathrm{CSE}_{\mathrm{uf}}$ the unit CSE at farm level. In turn $\mathrm{PSE}_{\mathrm{p}}$ can be defined as:

$$
\operatorname{PSE}_{\mathrm{p}}=\mathrm{Q}_{\mathrm{P}}\left(\mathrm{P}_{\mathrm{pd}}-\mathrm{P}_{\mathrm{pw}}\right)+(\mathrm{D}+\mathrm{I})-\mathrm{L}
$$

where $\mathrm{Q}_{\mathrm{P}}$ is the level of output at the processor level; $\mathrm{P}_{\mathrm{pd}}$ is the domestic processing output price; $\mathrm{P}_{\mathrm{pw}}$ is the world price of the processed product. $\mathrm{D}$ refers to any direct payments to processors; L represents levies on processors; and I refers to indirect payments to processors and all other state-financed support to this point in the chain.

The technical coefficient in [3] represents the amount of the farm level commodity that is required to produce a given level of the processing level commodity, e.g. the number of tonnes of wheat required to produce one tonne of flour. The unit CSE is the difference between the domestic price and the world price of the farm level output. Where international trade occurs, a similar adjustment is made if domestic and 
export prices differ and these differences are felt by producers i.e. a food processor sells part of their output on the domestic market at a different price from what they receive from export sales.

The reference prices for farm and processed level goods are derived from average prices at a country's own borders. This study will follow the general rule adopted in OECD studies. The free-on-board (f.o.b.) border price is chosen if a country is a net exporter, while a price including cost, insurance, freight (c.i.f.) will be chosen for a net importer, on the basis that these prices represent the opportunity cost to the producers and consumers of the country in question. Where no trade occurs, a problem emerges as to what the reference price should be in the absence of an import or export parity price. This is a particular problem for the milk chain (a commodity which is not usually traded internationally), and for calculating transfers at the retail level. In the case of milk the New Zealand farmgate price is used as a reference price. This approach has been taken in previous studies (OECD, 1996). Since, for most of the products analysed, there is little or no trade in the retail product, to calculate retail reference prices the processor reference price is taken and a suitable international margin added. The conversion coefficients used were derived from USDA (1989). For domestic prices, the actual observed prices in each country are used rather than any administratively set support prices.

In estimating the economic transfers only support measures that are specifically targeted at the agro-food chain are considered. Policies that are not specifically designed to benefit the agricultural and food sectors, but still impinge on them, are not considered. This assumption is made by the OECD and by following this precedent the figures generated here can be more easily compared with the results from previous reports (OECD, 1996). Finally the absolute levels of PSEs will fluctuate with exchange rate movements. These variations may be substantial and are exogenous to the agricultural situation (Peters, 1988). This is an important issue and it is essential to evaluate to what extent changes in nominal PSEs are due to exchange rate adjustments or real policy reforms. 


\section{AN OVERVIEW OF THE TRANSFER ESTIMATIONS}

PSEs may be expressed in three forms: total PSE, per unit PSE and \%PSE (expressed as a percentage of the value of output at domestic prices). The results of applying the transfer calculations are summarised in Table 1. The PSEs in Table 1 are calculated by summing the total value of transfers for the five main commodities for each stage of the food supply chain and dividing by the total value of production for the five products combined at the appropriate stage of the chain (expressed as a \%).

Table 1: Percentage PSEs for 5 Key Commodities along CEEC Food Supply Chains

1994

Farm

Processing

Retail

Consumer (CSE)

1996

Farm

Processing

Retail

Consumer (CSE)

$\begin{array}{cr}\text { Bulgaria } & \text { Czech } \\ -26 & -3 \\ 8 & 34 \\ 41 & 28 \\ -33 & -51\end{array}$

Hungary
n.a.
n.a.
n.a.
n.a.

Poland*
1
37
65
-61

$\begin{array}{cc}\text { Romania } & \text { Slovenia } \\ 30 & 49 \\ -20 & 4 \\ 3 & 34 \\ -3 & -65\end{array}$

* processing, retail and consumer calculations for Poland exclude chicken and beef due to missing data.

Reviewing Table 1, a considerable degree of variation between the six countries is apparent. For the period 1994 to 1996, farmers in Bulgaria and, to a lesser extent, the Czech Republic were consistently taxed while in Romania and Slovenia farmers were effectively protected. In Poland and Hungary the average figures are close to 1 and this reflects how positive support for some products was offset by effective taxation on others (Appendix 1). In Bulgaria and the Czech Republic while overall farmers were taxed, the main beneficiaries of these transfers have been processors and retailers, rather than final consumers. In Romania, state control of processing enterprises and margin controls meant in the period up to 1996, processors absorbed the losses in the chain. In Slovenia, the main losers have been final consumers who have had to pay prices substantially above world market equivalents with farmers, retailers and processors all effectively protected. In Hungary and Poland consumers have also had 
to pay overall above world market equivalent prices for food but this arose from transfers to processors and large retail margins, rather than support to farmers.

While indicating that, compared to international prices at each point in the food chain, distortions are present in CEEC food supply chains, the PSE analysis does not in itself explain the causes of these distortions. The transfers observed could be due to a combination of three factors: policy measures, market imperfections (structural characteristics of the market) and general $x$-inefficiency. In order to consider the relative importance of these three types of distortions a number of proxies have been taken. In considering the degree of market imperfection in each of the supply chains, it is useful to consider the number of firms operating at each stage, entry and exit levels, concentration ratios, price margins and the share of output accounted for by the private sector. Government policy can be scrutinised in terms of domestic support given to economic actors, price controls, and the trade regime. Finally, measures of $\mathrm{x}$ inefficiency include the output to employment ratio, cost structures, wastage and the market orientation of firms. To better understand these factors interviews were conducted and net margins calculated for all six countries and a survey of food processors was administered in Slovenia, Hungary, Czech Republic and Poland. The next three sections analyse the transfer estimations in greater detail and the factors creating these distortions are discussed.

\section{TRANSFERS AT FARM LEVEL}

Percentage PSEs by commodity at farm level are detailed in Appendix 1. ${ }^{1}$ In 1996 the largest aggregate PSE was recorded for Romania and this stemmed from the sizeable budget subsidies and trade protection afforded by the previous nonreformist government. Since 1996, due to the imposition of a structural adjustment programme, budgetary support has been substantially cut and effective protection has fallen in Romania (Gorton and Deaconescu, 1998). Slovenia recorded the largest relative support to farmers in 1996 (total transfers were lower due to the small size of the 
country). These supports have been substantial: in 1996 the unit PSE for wheat, milk, beef and pork were 55, 131, 1662 and 531 ECUs per tonne respectively. In the same year the five product total PSEs in Hungary and Poland were modest and this reflected how positive PSEs for some products were offset by negative results for other commodities. For Hungary in 1996 the figures for milk and pork were positive, while the reverse was true for wheat, beef and chicken. In Poland, negative figures were recorded for milk, beef and pork with positive PSEs estimated for wheat and chicken. In Poland, the PSEs for wheat and chicken have been consistently positive throughout the transitional period and this reflects the substantial trade controls for both products. The PSE for beef has been consistently negative throughout the period in both countries. As real incomes fell in the CEECs the demand for beef appeared to be more income and price elastic than other meats and prices for beef and veal have tended to be low in all countries apart from Slovenia (Appendix 3). In the Czech Republic and Bulgaria, up to 1996, the five product total PSEs were consistently negative. In the Czech Republic this reflected trade controls on the export of wheat and flour (with an attempt to keep prices low in a period of high international grain prices) combined with modest budgetary support.

Table 2 records the contribution of the market price effect to total PSEs (expressed as a percentage of the latter). For Bulgaria in 1996, the market price effect exceeded the total PSE as both figures were negative and the latter was only partially offset by the modest level of budgetary support (Table 3) and, to a greater extent for the livestock products, by a farm feed adjustment. While livestock producers were effectively taxed because their output prices were below adjusted border prices, this negative transfer was partially offset by them being able to purchase feed grains at below adjusted border prices. The 1996 results for Bulgaria, however, need to be treated with caution, as the year was characterised by a macroeconomic crisis with high inflation, rapid depreciation of the Bulgarian lev and negative economic growth. Changes in the exchange rate can have substantial impact on PSEs and this was

\footnotetext{
${ }^{1}$ Due to limitations of space only percentage PSEs are shown in this paper. The full set of results, including unit and total PSEs are detailed in Gorton and Buckwell (1998) for Bulgaria and Romania and, for all six countries in, Gorton et al., (1999).
} 
investigated by Gorton et al. (1997) who conducted sensitivity analysis on the Bulgarian results.

$\begin{array}{lcccccc}\text { Table 2: Market Price Element of the PSE as \% } & \text { of total PSE (1996) } & & \\ \text { Wulgaria } & \text { Czech } & \text { Hungary } & \text { Poland } & \text { Romania } & \text { Slovenia } \\ \text { Wheat } & 112 & 97 & 124 & 71 & 82 & 76 \\ \text { Milk } & 100 & 99 & 92 & 101 & -103 & 82 \\ \text { Pork } & 193 & 100 & 52 & 71 & 58 & 100 \\ \text { Beef } & 114 & 99 & 246 & 74 & 321 & 89 \\ \text { Chicken } & 108 & 98 & 112 & 120 & 53 & 106\end{array}$

$\begin{array}{lcc}\begin{array}{l}\text { Table 3: Government Spending on Agriculture (1996) in Mio ECU } \\ \text { Country } \\ \text { Spending (MECU) }\end{array} & \begin{array}{c}\text { Spending per capita } \\ \text { (ECU) }\end{array} \\ \text { Bulgaria } & 16 & 1.93 \\ \text { Czech Republic } & 60 & 5.81 \\ \text { Hungary } & 485 & 48.01 \\ \text { Poland } & 488 & 12.64 \\ \text { Romania } & 574 & 25.39 \\ \text { Slovenia } & 45 & 22.95\end{array}$

In Romania, by contrast, farmers have been effectively supported and this was due to a combination of both the trade regime, with substantial import duties, and price support to farmers. Government subsidies were especially important in propping up state owned pig and poultry complexes. In these cases the market price effect accounted for only $58 \%$ and $53 \%$ of total PSEs respectively in 1996. However, farmers were penalised by high relative input prices, which apart from a farm feed adjustment are not considered in the PSE calculations (Gorton and Deaconescu, 1998).

The estimations for the Czech Republic indicate that market price effects dominate total PSEs. In this country government budgetary support to agriculture has been comparatively small (Table 3). Since 1996, budgetary support has risen in real terms and farm level PSEs, as calculated by the OECD, have increased (OECD, 1998). In Hungary, government spending in absolute and per capita terms has been much higher and this has been particularly important in financing export subsidies. These subsidies have been particularly important for the export of pork and dairy products for which farm level PSEs have been positive. In 1996 and 1997 no subsidies were required for the export of wheat due to Hungarian prices being below adjusted border prices. 
In Poland, $71 \%$ of the PSE for wheat was accounted for by the market price effect in 1996 with the remainder from government support. As wheat is the most important crop, its share of noncommodity specific support (such as extension services) allocated to it in the PSE calculations is high. The effective protection of grain farmers led to a negative farm feed adjustment (Polish livestock farmers were penalised on this input) and this offset the positive market price effect in the case of chicken and exacerbated the effective taxation on pork and beef farmers in 1996.

Finally, Slovene farming is highly protected and effectively subsidised. In each case (five products, three years) PSEs were positive at the farm level with the most protected sectors being milk and beef farming. Beef farming has become successively more protected due to government engineered price increases and considerable budgetary intervention. In contrast, the PSE for wheat declined between 1994 and 1996. This decline was, however, not due to lessening domestic support but rather a slower growth of domestic prices compared to the considerable increase in world market prices during this period (Rednak et al., 1997). Overall, in 1994 the five product farm level total PSE for Slovenia was nearly 216m ECU and in 1996, over $227 \mathrm{~m}$ ECU.

\section{PROCESSING LEVEL TRANSFERS}

Appendix 2 records the transfers at the processing level in the form of percentage PSEs. With the exception of Romania, overall processing level transfers were positive for all countries in 1994 and 1996 (Table 1). The highest relative degree of protection was recorded in the Czech Republic and Poland. In the Czech Republic processors have benefited from low farmgate prices without passing on benefits to consumers. In Slovenia, while processing level output prices have been substantially above adjusted border prices this transfer was substantially offset by manufacturers having to pay above international prices for their inputs. In Poland markups on pork and flour have been substantial and in Hungary pork, chicken and bread recorded positive PSEs. Finally for Bulgaria, total PSEs have been positive at the processing level and processors appear to have extracted some of the rents accrued from the effective taxation of farmers. 
As discussed above, these transfers can be caused by three main factors: government policy (trade and budgetary support/taxation), market imperfections and $\mathrm{x}$-inefficiencies and these were investigated for each country. The negative transfers recorded for Romania resulted mainly from government intervention, with the PSEs for milk and bread being consistently negative throughout the period. This reflected the margin controls imposed on bakeries and dairies for these two staples. The cost estimations on which these controls and margins were based only loosely resembled actual costs. When rapid inflation invalidated the cost estimations, permitted margins were adjusted too slowly. As a result bakeries and dairies tried to produce goods containing additives such as pastries and some cheeses, which were not subject to price controls and for which margins were better. However, the state owned processors which accounted for the majority of output during this period were more restricted and accumulated huge debts. This has hindered their privatisation.

In Slovenia, government intervention has also been important in shaping the transfers but in this case trade protection has been paramount. Slovenia's tariffs are high and this has insulated domestic producers against international competition. For example Slovenia's World Trade Organization (WTO) commitments for beef involves an initial binding of 129 and a final binding of 83 (ad valorem equivalent). The corresponding figures for white sugar are 174 and 127 and for butter 141 and 127 (OECD, 1997). While Slovenia is a member of CEFTA, for agricultural products no free trade was initially envisaged although the General Agreement does allow for the granting of bilateral concessions (which have now been implemented).

This support has augmented the profitability of food processing in Slovenia. Figure 2 details the profitability of the Slovenian food industry as a whole and for the individual branches. Profitability in this study was measured by calculating the cash flow as a percentage of turnover, where the former is defined as turnover minus input costs (raw materials and labour costs). This follows the procedures taken in two comparable studies: Viaene and Gellynck's (1995) analysis of the profitability of leading German food, drink and tobacco enterprises and Kowrygo et al.'s evaluation 
of the evolution of profitability in the Polish food industry in the early 1990s. For Slovenia the average profitability of enterprises is approximately six percent, with alcoholic and nonalcoholic beverages and other food production shown to be the most profitable. The average profitability of the 100 leading German food manufacturers in 1990 was $4.4 \%$ (Viaene and Gellynck, 1995: 290). However profitability varied markedly with the size of enterprise: the average figure for the top twenty-five firms was over $6 \%$ compared with just over $2 \%$ for numbers seventy-six to one-hundred in the list of largest German food manufacturers. Kowrygo et al., (1997) found much lower figures for Poland.

Figure 2: The comparative profitability of Slovenian, Polish and German Food Industries (1996)

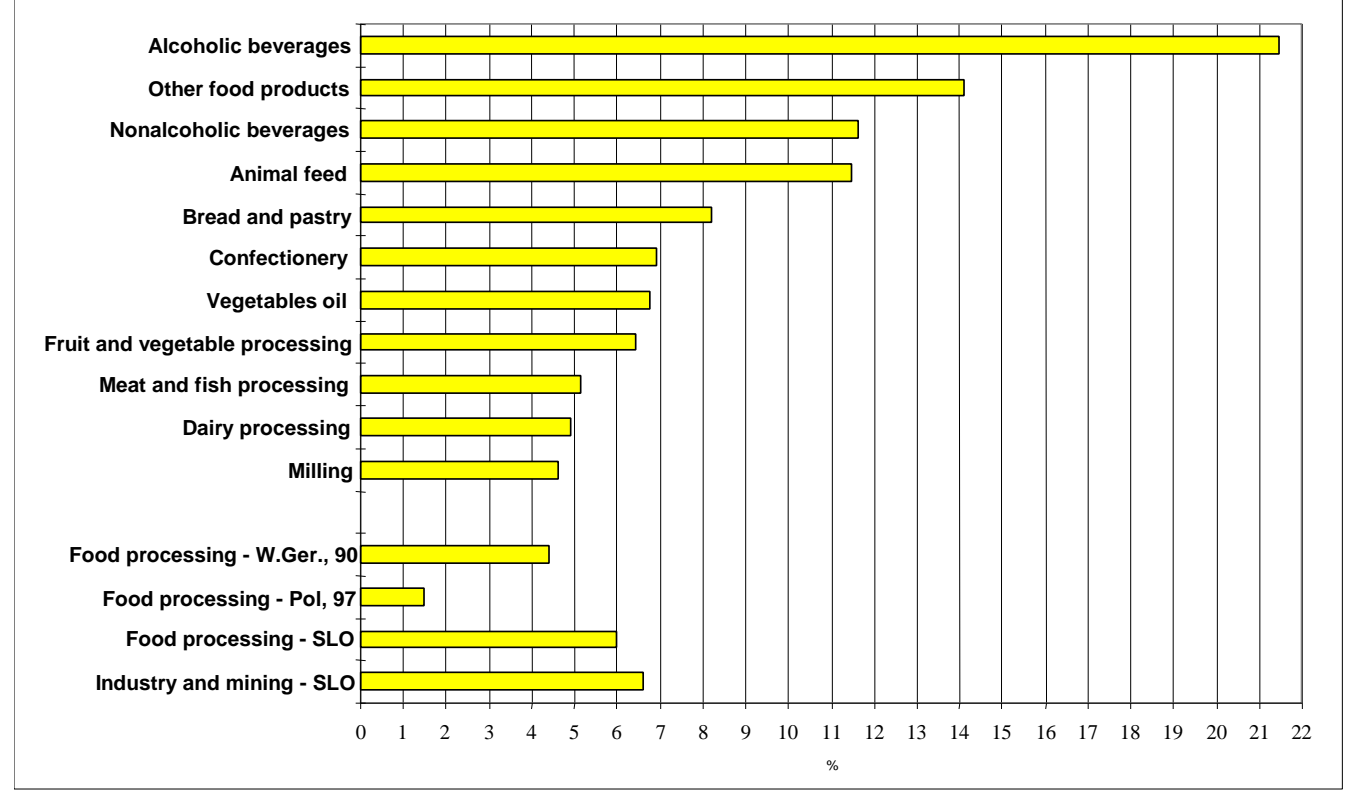

Slovenia's future accession to the EU and membership of an enlarged Single European Market (SEM) will substantially change this operating environment. Currently, firms are largely oriented to the domestic market, which has been protected by trade barriers and other forms of government intervention. This has allowed the sector as a whole to be profitable albeit with substantial variations between branches. Profit levels are higher than in Germany and Poland and if Slovenia joins the EU it will face greater competitive pressures. Manufacturers operating in an enlarged SEM will not be afforded the degree of protection they currently receive. 
In Bulgaria and the Czech Republic, processors have been able to capture some of the rents accrued by the effective taxation on farmers. Farmgate prices as a percentage of retail prices in the Czech Republic have been very low (Table 4). For example the price of one tonne of wheat at farmgate was only $13 \%$ of the retail output price of one tonne of bread in the Czech republic in 1996. This compared to $37 \%$ in Romania. The equivalent figures for pork, beef, chicken and milk in the Czech Republic was $27 \%, 26 \%, 40 \%$ and $63 \%$ respectively in 1996 as opposed to $57 \%$, $67 \%, 50 \%$ and $72 \%$ in Romania. In Bulgaria a similar pattern of low farmgate prices as a percentage of retail prices emerges. This is particularly true for the three meats: pork, beef and chicken.

Table 4: Price Margins Along CEEC Food Supply Chains (1996)

Figures expressed as a $\%$ of retail prices

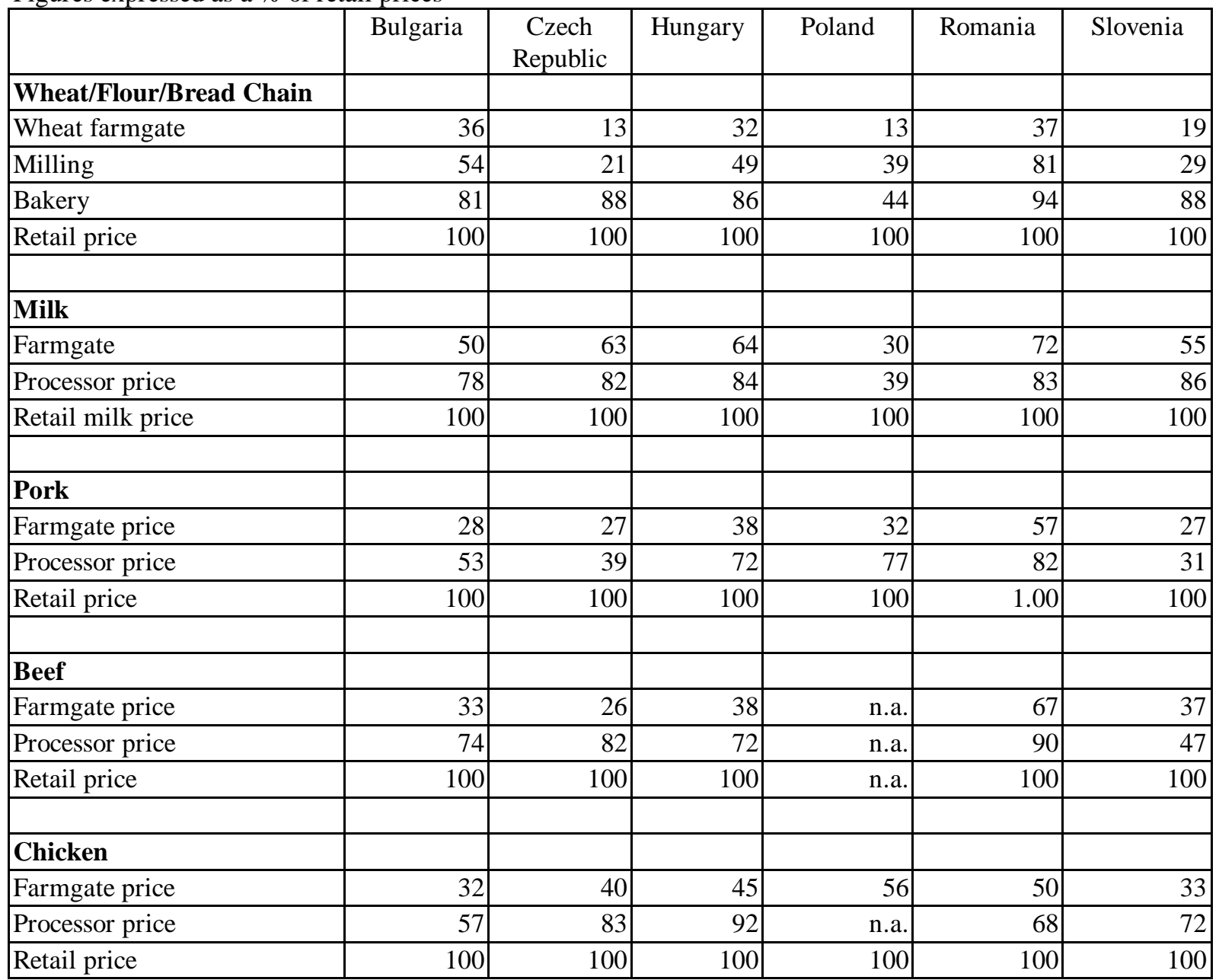

It has often been argued that excessive concentration is a major problem in the CEECs and Table 5 records the four firm concentration ratios calculated as part of this project. With the exception of flour in Bulgaria, concentration ratios are low in 
Romania, Bulgaria and the Czech Republic relative to Western Europe. In part this is due to the policy of the former regimes in each of these countries to build up plants on a 'one per county' basis for staple products (meats, milling and milk). In Bulgaria this meant at least one per okrug, which given the fact there were twenty-eight administrative districts means that for these sectors at least no one enterprise has significant price-making potential. As the quality and quantity of raw materials available to processors has decreased and with large scale overcapacity in the dairy, milling and slaughtering industries, firms have had to go outside their local district to procure agricultural raw materials. In Romania a similar 'one per judet' policy was followed.

Table 5: Four-firm concentration ratios in selected European countries, 1996*

$\begin{array}{lrrll} & \text { Flour } & \text { Bread } & \begin{array}{l}\text { Processed Meat } \\ \text { (pork and beef) }\end{array} & \text { Milk } \\ \text { France } & & & 23.0 & \text { n.a. } \\ \text { Germany } & 29.0 & 4.5 & 22.0 & \text { n.a. } \\ \text { Italy } & 38.0 & 7.0 & 11.0 & \text { n.a. } \\ \text { UK } & 6.7 & 4.0 & \text { n.a. } & \\ & 76.0 & 58.0 & & 26.7 \\ \text { Czech Republic } & 18.0 & & 15.7 & 35.0 \\ \text { Hungary } & 30.0 & \text { n.a. } & 40.0^{* *} & 19.3 \\ \text { Poland } & 20.0 & 10.7 & 11.5 & 35.2(1995) \\ \text { Bulgaria } & 47.6 & 6.9 & 15.1 * * & 31.2 \\ \text { Romania } & 8.5 & 9.1 & 11.6 & 76.0 \\ \text { Slovenia } & 100.0 & 45.5 & 55.6 & \end{array}$

*figures for Western Europe relate to 1990 (Sutton,1991), ** data for pork products only

Processing in Hungary and, especially, Slovenia is more concentrated. The figures for Hungary reflect greater openness to FDI and the priority placed on inward investment over competition policy. From the interviews conducted excessive concentration was only thought to be an issue for the production of margarine, other edible oils and refined sugar in Hungary. When the vegetable oil enterprise (NOMOV) was privatised, a single company for the manufacture of vegetable oil and a separate single production entity for margarine (later sold to Unilever) were created. This has led to some problems in effective competition:

For special inputs there are some monopolies, such as vegetable oil. Sometimes we buy from import but this is more expensive because of customs duties (bakery, Budapest). 
The high concentration in Slovenia reflects its small size and oligopolistic nature of competition that is compounded by the high levels of trade protection. In Bulgaria and Romania the main structural inefficiency is not excessive concentration but rather excessive fragmentation at the farm level for livestock production. With average herd size below two milking cows in both countries, economies of scale are not being realised and transaction costs are very high. For example, one of the largest dairies in Bulgaria, based in Dobrich, reported that they are dealing with 50,000 farmers via collecting stations scattered throughout the region. As the director of the dairy in Dobrich remarked 'to keep up with 50,000 farmers I need 2,000 accountants.'

Small farmers with one or two cows produce largely for their own consumption with only surplus milk sold for processing. This has led to highly erratic and substantially reduced supplies to dairies so that most are operating at between 10 and $25 \%$ of full capacity. The milk they receive tends to have a high bacterial content, high acidity and low dry matter. This often leads to a situation where milk deliveries are only suitable for cheese production. In Hungary and the Czech Republic the situation is much more favourable as they have managed to keep their large farm structures intact. For example in 1996, in the Czech Republic average herd size (all farm types) was 109 cattle, 249 pigs and 1,933 chickens. Even on private farms the respective figures were 21 cattle, 31 pigs and 436 chickens (CR Podle Agrocenzu, 1997).

Table 6 details the results from the survey of processors in Slovenia, Hungary and the Czech Republic. The survey asked for respondent beliefs about the importance of various factors acting as present barriers to growth. Respondents were asked to rank the importance of various factors on a scale of one to four. One describes a situation of the factor being unimportant with four, at the other end of the scale, indicating the factor to be a major barrier or of vital importance and Table 6 presents the average scores for each factor. 
Table 6: Barriers to growth reported by respondents

\begin{tabular}{|l|c|c|c|}
\hline Type of barrier & \multicolumn{3}{|c|}{ Average Scores } \\
\hline & Czech Republic & Hungary & Slovenia \\
\hline Exchange rate instability & 2.16 & 2.52 & 2.04 \\
Inflation & 2.41 & 3.17 & 2.69 \\
Interest rate levels & 3.19 & 3.15 & 2.77 \\
Access to credit & 2.45 & 2.43 & 2.38 \\
Activities of organised crime and & 1.58 & 2.03 & 1.73 \\
$\quad$ gangsters & 1.74 & 1.57 & 2.67 \\
Government price controls & 1.25 & 2.62 & 2.67 \\
Other government intervention & 2.48 & 2.02 & 2.23 \\
Your company having high & & & \\
$\quad$ debt levels & 3.44 & 2.70 & 3.54 \\
Late payment by customers & 2.10 & 1.29 & 2.21 \\
Enforcement of bankruptcy laws & 1.90 & 1.91 & 1.83 \\
Activities of state monopolies & 1.61 & 1.49 & 0.94 \\
Problems with privatisation & &
\end{tabular}

Source: Survey (1997)

The highest average score in the Czech Republic and Slovenia (most important barrier to growth) was recorded for late payment by customers. The importance attached to problems of late payment also emerged from the interviews conducted:

Late payment is our biggest problem. We have to pay farmers in 20 days but hotels and restaurants take two to three months before they pay but we do not receive any interest (small meat processor and retail outlet, north-east Slovenia).

The problem of cash flow management and access to credit has been exacerbated by the high level of interest rates (second most important barrier to growth based on average scores in all three countries). High values were also attached to government intervention and restrictions on price controls. Very few firms ranked the activities of organised crime and gangsters as being of major importance in Slovenia and the Czech Republic. In Hungary it is ranked higher but still below the main macroeconomic considerations of access to credit, level of interest rates and exchange rate instability. 
Interviewees in all three countries did remark, however, that many small producers have been able to avoid taxes and regulations:

These private bakeries five years ago only had $10 \%$ market share whereas today it is $50 \%$. They enjoy good margins and avoid paying taxes and do not register employees. We estimate that there are ninety bakeries without formal employees. They do not declare all their invoices and pay no sales tax. It is slowing down growth in this sector (milling, and baking enterprise, Slovenia).

In the last two years the situation has stabilised as there is more strict legislation. Before many not pay taxes and there was not strict accountancy (dairy enterprise, Czech Republic).

\section{RETAIL AND CONSUMER LEVEL TRANSFERS}

The most consistently positive PSEs have been recorded at the retail level (Appendix 3). With the exception of Romania in 1996, the average retail PSEs were positive for all countries in 1994 and 1996. The exception of Romania was caused, as discussed above, by the imposition of margin controls on key food products. These controls were exacted to keep consumer prices artificially low for basic food goods (CSEs were positive) without taxing farmers. This meant that processors and retailers absorbed the losses in the chain. In the Czech Republic, retail PSEs were positive in all but one of fifteen cases (five products, three years). In Hungary only one negative PSE was recorded for only product (bread in 1996) out of ten cases. In Bulgaria, retailers have been the main beneficiaries of the transfers from farmers, especially in the early years of transition. The figures for Poland suffer from missing data but are consistently positive for milk. Finally, in Slovenia in only one case was a negative PSE estimated (bread in 1995).

Some commentators have queried the findings of highly positive PSEs and margins at the retail level, arguing that the results are counterintuitive given the absence of concentrated market power (Swinnen, 1998). Clearly the calculations of transfers at retail / consumer level are hindered by the difficulty of obtaining meaningful international prices at this level. However, the results can be argued to be consistent with expectations for a transition economy on two counts. First, it is important to remember that under communism, consumer industries were suppressed in favour of heavy industry, so at the outset of transition the retail sector was underdeveloped with a potential for growth. Second, privatisation at the retail level 
was easiest to achieve as it required little capital and few specialist skills. In any industry where supernormal profits exist one would expect to see significant numbers of new entrants and a rise in the total stock of businesses ${ }^{2}-$ this is just the operation of Smith's 'invisible hand.'

Looking at the profile of the food retailing sector in four CEECs (Table 7), the number of firms increased year by year despite the macroeconomic downturns experienced in the 1990s which in the case of Bulgaria was of crisis proportions. The market structure figures are consistent with the positive transfer estimations recorded for Hungary, Poland, the Czech Republic and Bulgaria. Finally, although in the long run one would expect to see such supernormal profits to be eroded as more firms enter the market, this process is unlikely to be immediate. For a firm to enter a market at least three requirements exist: (i) knowledge of the sector's profitability and likely returns, (ii) sufficient capital for market entry and (iii) an entrepreneurial propensity to accept the risks involved. In Bulgaria the environment for firm formation has been highly unstable, given the macroeconomic crisis with conflicting trends, high nominal interest rates and a shortage of bank credit. The notion of the persistence of structural imbalances within this environment appears highly justifiable and in fact it would be more surprising if one had found simultaneous adjustment had occurred.

Table 7: The Market Structure of CEEC Retail Sectors

\section{Bulgaria}

Bread and bread products retail outlets Meat \& meat products retail outlets

Dairy products retail outlets

\section{Hungary}

Number of food retail outlets

Poland

Number of food, drinks and tobacco retail outlets

\section{Czech Republic}

Number of retail enterprises
1994

33,320

30,419

30,050

54,901

169,231

206,000
1995

35,051

32,563

31,794

58,590

n.a.
1996

n.a.

n.a.

n.a.

59,943

180,548

\footnotetext{
${ }^{2}$ In the absence of prohibitory barriers to entry.
} 
In the CEECs one would expect these transfers to be eroded as new foreign owned retail chains enter the market and it will be interesting to monitor future developments.

Turning to the consumer level (Appendix 4), final consumers were effectively taxed overall in all but two cases. These two cases were Romania and Bulgaria in 1996 (the latter only marginally). The highest relative taxation was recorded in Slovenia, where final consumers pay the price for positive PSEs at all three previous stages of the chain. The degree of agricultural support in Slovenia, of all the CEECs, is closest to the EU and one would expect highly positive farm level PSEs and as a result high effective taxation of consumers. In the Czech Republic, Hungary and Poland, consumers have suffered from relatively high PSEs at processing and retail levels. In the early years of transition Bulgarian consumers did not see the benefits of low farmgate prices as transfers were accrued by retailers, and to a lesser extent processors. In 1996 consumers were marginally supported in Romania as a result of the margin controls placed on processors and retailers, but this system was unsustainable in the long run.

\section{CONCLUSIONS}

The extension of the PSE/CSE methodology is useful in that it allows a view of whole agro-food chains so that the magnitude and direction of economic transfers between actors at each stage can be estimated. Considering all the stages of the supply chain (farm, processing, retail and consumer), farm level transfers are the most consistent.

For the period 1994 to 1996, farmers in Bulgaria and the Czech Republic were taxed while in Romania and Slovenia farmers were effectively protected. In Bulgaria and the Czech Republic the main beneficiaries of these transfers have been processors and retailers, rather than final consumers. In Poland and Hungary, the positive support for some products at the farm level was offset by effective taxation on others. In Romania, state control of processing enterprises and margin controls meant in the period up to 1996, processors absorbed the losses in the chain. In Slovenia, the main losers have been final consumers who have had to pay prices substantially above world 
market equivalents with farmers, retailers and processors all effectively protected. In Hungary and Poland consumers have also had to pay, overall, above world market equivalent prices for food but this arose from transfers to processors and large retail margins, rather than support to farmers. The factors causing these transfers are summarised in Table 8 and from this analysis a number of policy relevant conclusions can be drawn.

Table 8: Summary of Factors Creating Transfers along CEEC Food Supply Chains

\begin{tabular}{|l|l|l|}
\hline Factor & Importance & Discussion \\
\hline Trade protection & High & $\begin{array}{l}\text { Export bans instrumental in maintaining the } \\
\text { effective taxation of farmers in Bulgaria and the } \\
\text { Czech Republic. Vital for ensuring high effective } \\
\text { support in Slovenia. }\end{array}$ \\
\hline $\begin{array}{l}\text { Agricultural budgetary } \\
\text { support }\end{array}$ & Low to Medium & $\begin{array}{l}\text { Small component of total PSEs. Insignificant in } \\
\text { Bulgaria and the Czech Republic (to 1996). In } \\
\text { Hungary and Poland farmers overall no better off } \\
\text { than if operating just at international prices. } \\
\text { Inefficiencies of policy support. }\end{array}$ \\
\hline $\begin{array}{l}\text { Concentration in } \\
\text { processing }\end{array}$ & Low & $\begin{array}{l}\text { Concentration ratios are low (apart from Slovenia } \\
\text { and some branches in Hungary). Competition for } \\
\text { raw materials, especially in processing industries } \\
\text { where significant overcapacity persists (meats and } \\
\text { dairy). }\end{array}$ \\
\hline $\begin{array}{l}\text { Government controlled } \\
\text { price margins }\end{array}$ & High (where applied) & $\begin{array}{l}\text { Important in creating negative transfers at the } \\
\text { processing level in Romania. }\end{array}$ \\
\hline $\begin{array}{l}\text { of retailing } \\
\text { fow }\end{array}$ & High & $\begin{array}{l}\text { Retail sector restricted under communism. Large } \\
\text { number of new entrants attracted by higher } \\
\text { margins in the transitional period. }\end{array}$ \\
\hline
\end{tabular}

The most immediate option to improve the welfare of farmers in Bulgaria and the Czech Republic is to remove the various export bans and trade restrictions which have been imposed on trade in agricultural commodities. Under the law of one price, one would expect farmgate prices to rise to international levels, with a small differential for transport and storage costs. The effective taxation on farmers has not delivered benefits to final consumers and these rents have tended to be accrued by intermediate actors. While overall most of the effective taxation on farmers has been removed in the CEECs, for some individual commodities negative transfers are still apparent. 
To meet the forthcoming challenge of accession to the EU it is desirable to complete privatisation programmes and resolve the questions of ownership that have inhibited production. Interviews with processors in all the CEECs indicated that a rapid conclusion to the privatisation process would be welcomed by managers in enterprises where ownership is uncertain; their main wish is 'to know where we stand.' While the mean rank for lack of privatisation as a barrier to growth in Table 6 is low, it was nonetheless deemed most important in enterprises where privatisation had yet to occur. Information on privatisation should be targeted to potential managerial or employee buyers with an agreement to write off some debts to help complete ownership changes.

The main structural inefficiency in the dairy supply chain in Bulgaria, Romania and, to a lesser extent, Poland rests at the farm level and centres on the small size of herds. With average herd sizes below two milking cows, economies of scale are not being realised and transaction costs are very high. With a vicious circle of low retained earnings and suboptimal asset bases, this problem could persist for a considerable tine unless assistance is given. The importance of improving cash flow management is highlighted in Table 6 and deserves further attention (Gow and Swinnen, 1998). The development of assisted leasing arrangements may be a method for increasing dairy herd sizes and insuring that the cows go to farmers who will farm them most efficiently. While many of the processors interviewed wanted to backwardly integrate themselves they lack the capital to undertake such a move.

With the exception of certain branches in Hungary and Slovenia, excessive concentration at the processing level does not appear to be a major impediment to efficiency. If these countries join an enlarged SEM, the protection currently afforded to them will disappear and greater competition will develop. This will significantly change the operating environment faced by Hungarian and Slovenian processors. 
If excessive concentration is a problem in Bulgaria and Romania it appears to be in the input industries, particularly agrochemicals. There are only five significant fertiliser-producing plants in Bulgaria with a high degree of differentiation. None of these plants have been privatised and are protected by high import duties for fertilisers. In Romania, none of the ten main fertiliser plants have been privatised and output prices are above world market levels (Gorton et al., 1998). By removing these trade and ownership restrictions, competitive pressures would increase and the price of agrochemical inputs should fall. This would benefit the beleaguered farming sector, which has been squeezed by input prices rising at a faster rate than output prices. Of all agricultural inputs and services, fertilisers are the closest to being pure private goods and are an obvious candidate for private supply (Carney, 1998).

The transfer estimates indicate that the largest net beneficiaries throughout the region have been retailers. The data on market structures is consistent with this: the retailing sector has grown rapidly since the outset of transition. As the sector grows and more firms enter the market, there will a tendency for economic rents to be bid down. Rather than attempting to impose price restrictions or controls on the retail sector which are likely to be almost impossible to enforce and in some cases counterproductive, support agencies should concentrate on facilitating market entry if barriers to entry exist and transfers are persistent overtime. In the retailing sector barriers to entry do not appear to be very significant in the majority of cases.

\section{References}

Carney, D. (1998). Changing Public and Private Roles in Agricultural Service Provision, London: ODI

Gorton, M. (1997). Task 3: an Analysis of the Economic Relations between the CEEC Food Industry and Agriculture Progress Report, Department of Agricultural Economics, Wye College, University of London 
Gorton, M., Buckwell, A. and Davidova, S. (1997). Impediments to Efficiency in the Agro-Food Chain: Bulgaria, Report to the Organization for Economic Cooperation and Development (OECD), Paris, September

Gorton, M., Buckwell, A. and Davidova, S. (1999). Transfers and distortions along CEEC Food Supply Chains: full results, EU FAIR Project on Agricultural Implications of CEEC-Accession to the EU (FAIR1-CT95-0029), mimeo

Gorton, M. and Deaconescu, D. (1998). The International Competitiveness of Romanian Agriculture, report presented to EU PHARE Technical Assistance Project, Bucharest

Gorton, M., Esanu, C., Deaconescu, C., Buckwell, A. and Davidova, S. (1998). Impediments to Efficiency in Romanian food supply chains, Report to the Organization for Economic Cooperation and Development (OECD), Paris, February

Gow, H. R. and J.F.M. Swinnen (1998). Up- and Downstream Restructuring, Foreign Direct Investment, and Hold-up Problems in Agricultural Transition. European Review of Agricultural Economics, Vol. 25, No. 3, pp. 331-350.

Ivanova, N., Lingard, J., Buckwell, A. and Burrell, A. (1995). Impact of changes in agricultural policy on the agro-food chain in Bulgaria, European Review of Agricultural Economics, pp.354-371

Kowrygo, B., Berger, S., Rejman, K. Halicka, E and Gorska-Warsewicz, H. (1997). Competitiveness of the Food and Drink Industry in Poland, Interim report of EU Phare Project No.P95-2015-R, Warsaw Agricultural University

OECD (1996). Agricultural Policies, Markets and Trade: Monitoring and Outlook 1996 in the Central and Eastern European Countries, New Independent States, Mongolia and China, Paris: OECD 
OECD (1997). Designing New Trade Policies in the Transition Countries, Paris: OECD, Doc No. OCDE/GD(97)199

OECD (1998). Agricultural Policies, Markets and Trade: Monitoring and Outlook 1998 in the Central and Eastern European Countries, New Independent States, Mongolia and China, Paris: OECD

Peters, G.H. (1988). The interpretation and use of Producer Subsidy Equivalents, Oxford Agrarian Studies, Vol.17, pp.186-218

Rednak, M., Erjavec, E. and Turk, J. (1997). The Level of Protection in Slovene Agriculture and Corresponding Policy Implications, Paper presented to the Final Workshop of the Phare Ace Programme on Agricultural Price Policies under Transition to Market, Chanian, $18-20^{\text {th }}$ April

Sutton, J. (1991). Sunk Costs and Market Structure, Cambridge: MIT Press

Swinnen, J.F.M. (1998). Economic transition and the distribution of policy rents: the case of the wheat - flour - bread chain in Bulgaria, European Review of Agricultural Economics, Vol.25, No.2, pp.243-258

USDA (1989). The International Food Retailing Sector, Economic Research Service, Agricultural and Trade Analysis Division

Viaene, J. and Gellynck, X. (1995). Structure, conduct and performance of the European food sector, European Review of Agricultural Economics, Vol.22, pp.282-295 


\section{APPENDICES}

Appendix 1: Percentage PSEs at Farm Level

1994

Wheat

Bulgaria

Czech Republic

Hungary

Poland

Romania

Slovenia

Milk

Bulgaria

Czech Republic

Hungary

Poland

Romania

Slovenia

Beef

Bulgaria

Czech Republic

Hungary

Poland

Romania

Slovenia

Pork

Bulgaria

Czech Republic

Hungary

Poland

Romania

Slovenia

\section{Chicken}

Bulgaria

Czech Republic

Hungary

Poland

Romania

Slovenia

n.a.

9

32

54

9

29

n.a.

$-22$

13

144

$-8$

2

n.a.

$-2$

6

48

$-20$

$-4$

n.a.

11

39

51

$-26$

$-16$

n.a.

18

33

18
1995

1996

1997
$-89$

$-61$

n.a.

25

$-4$

41

19

28

n.a.

10

$-29$

162

0

9

n.a.

$-5$

8

59

$-9$

4

n.a.

10

32

46

$-13$

$-21$

n.a.

21

7

27
$-68$

$-46$

$-3$

16

28

29

100

24

31

$-11$

$-6$

131

$-110$

9

$-3$

$-9$

$-6$

61

$-20$

11

5

$-2$

41

32

$-125$

$-15$

$-34$

15

17

39 n.a.

n.a.

$-14$

7

n.a.

n.a.

n.a.

n.a.

n.a.

n.a.

n.a.

n.a.

$-8$

n.a.

n.a.

n.a.

n.a.

6

n.a.

n.a.

n.a.

n.a.

$-37$

2

n.a.

n.a. 
Appendix 2: Percentage PSEs at Processing Level

\begin{tabular}{|c|c|c|c|c|}
\hline & 1994 & 1995 & 1996 & 1997 \\
\hline \multicolumn{5}{|l|}{ Flour } \\
\hline Bulgaria & 17 & 24 & 19 & n.a. \\
\hline Czech Republic & 17 & 16 & -8 & n.a. \\
\hline Hungary & n.a. & n.a. & -11 & -23 \\
\hline Poland & 46 & 54 & 51 & 51 \\
\hline Romania & -83 & -55 & -151 & n.a. \\
\hline Slovenia & 18 & 33 & 15 & n.a. \\
\hline \multicolumn{5}{|l|}{ Bread } \\
\hline Bulgaria & 12 & 14 & 0 & n.a. \\
\hline Czech Republic & 58 & 63 & 59 & n.a. \\
\hline Hungary & n.a. & n.a. & 63 & 79 \\
\hline Poland & n.a. & n.a. & n.a. & n.a. \\
\hline Romania & -27 & -38 & -92 & n.a. \\
\hline Slovenia & -79 & -100 & -7 & n.a. \\
\hline \multicolumn{5}{|l|}{ Milk } \\
\hline Bulgaria & -164 & 87 & 33 & n.a. \\
\hline Czech Republic & -49 & 28 & 24 & n.a. \\
\hline Hungary & n.a. & n.a. & -88 & -89 \\
\hline Poland & 8 & 18 & 8 & -3 \\
\hline Romania & -23 & -117 & -50 & n.a. \\
\hline Slovenia & -1 & -7 & 2 & n.a. \\
\hline \multicolumn{5}{|l|}{ Beef } \\
\hline Bulgaria & 10 & -135 & -21 & n.a. \\
\hline Czech Republic & 21 & 21 & 24 & n.a. \\
\hline Hungary & n.a. & n.a. & 17 & 102 \\
\hline Poland & n.a. & n.a. & n.a. & n.a. \\
\hline Romania & -30 & -49 & -196 & n.a. \\
\hline Slovenia & -3 & -21 & -36 & n.a. \\
\hline \multicolumn{5}{|l|}{ Pork } \\
\hline Bulgaria & 12 & -58 & 18 & n.a. \\
\hline Czech Republic & 21 & 11 & 3 & n.a. \\
\hline Hungary & n.a. & n.a. & 105 & 103 \\
\hline Poland & 54 & 61 & 58 & 48 \\
\hline Romania & 38 & 16 & 23 & n.a. \\
\hline Slovenia & -24 & 100 & 100 & n.a. \\
\hline \multicolumn{5}{|l|}{ Chicken } \\
\hline Bulgaria & -5 & 17 & 66 & n.a. \\
\hline Czech Republic & 28 & -4 & 16 & n.a. \\
\hline Hungary & n.a. & n.a. & 18 & 19 \\
\hline Poland & n.a. & n.a. & n.a. & n.a. \\
\hline Romania & 29 & -23 & 8 & n.a. \\
\hline Slovenia & 35 & 22 & 19 & n.a. \\
\hline
\end{tabular}




\section{Appendix 3: Percentage PSEs at Retail Level}

\begin{tabular}{|c|c|c|c|c|}
\hline & 1994 & 1995 & 1996 & 1997 \\
\hline \multicolumn{5}{|l|}{ Bread } \\
\hline Bulgaria & -2 & 3 & -11 & n.a. \\
\hline Czech Republic & 41 & 42 & 36 & n.a. \\
\hline Hungary & n.a. & n.a. & 0 & 8 \\
\hline Poland & n.a. & n.a. & n.a. & n.a. \\
\hline Romania & -27 & -38 & -220 & n.a. \\
\hline Slovenia & 20 & 0 & 1 & n.a. \\
\hline \multicolumn{5}{|l|}{ Milk } \\
\hline Bulgaria & -15 & 17 & 22 & n.a. \\
\hline Czech Republic & 4 & -5 & 6 & n.a. \\
\hline Hungary & n.a. & n.a. & 101 & 99 \\
\hline Poland & 65 & 56 & 53 & 55 \\
\hline Romania & 4 & -102 & -63 & n.a. \\
\hline Slovenia & 0 & 9 & 6 & n.a. \\
\hline \multicolumn{5}{|l|}{ Beef } \\
\hline Bulgaria & 49 & -15 & -18 & n.a. \\
\hline Czech Republic & 8 & 15 & 9 & n.a. \\
\hline Hungary & n.a. & n.a. & 25 & 6 \\
\hline Poland & n.a. & n.a. & n.a. & n.a. \\
\hline Romania & -64 & -110 & -167 & n.a. \\
\hline Slovenia & 53 & 48 & 49 & n.a. \\
\hline \multicolumn{5}{|l|}{ Pork } \\
\hline Bulgaria & 51 & 32 & 31 & n.a. \\
\hline Czech Republic & 57 & 64 & 62 & n.a. \\
\hline Hungary & n.a. & n.a. & 53 & 100 \\
\hline Poland & n.a. & n.a. & n.a. & n.a. \\
\hline Romania & 36 & 22 & 9 & n.a. \\
\hline Slovenia & 58 & 78 & 73 & n.a. \\
\hline \multicolumn{5}{|l|}{ Chicken } \\
\hline Bulgaria & 9 & 14 & 23 & n.a. \\
\hline Czech Republic & 12 & 2 & 5 & n.a. \\
\hline Hungary & n.a. & n.a. & 2 & 2 \\
\hline Poland & n.a. & n.a. & n.a. & n.a. \\
\hline Romania & 13 & -27 & -10 & n.a. \\
\hline Slovenia & 16 & 19 & 21 & n.a. \\
\hline
\end{tabular}




\section{Appendix 4: Percentage CSEs at Consumer Level}

Bread
Bulgaria
Czech Republic
Hungary
Poland
Romania
Slovenia
Milk
Bulgaria
Czech Republic
Hungary
Poland
Romania
Slovenia
Beef
Bulgaria
Czech Republic
Hungary
Poland
Romania
Slovenia
Pork
Bulgaria
Czech Republic
Hungary
Poland
Romania
Slovenia
Chicken
Bulgaria
Czech Republic
Hungary
Poland
Romania
Slovenia

1994

1995

1996

1997

Bread

Czech Republic

n.a.

$-61$

n.a.

$-59$

$-53$

$-28$

n.a.

n.a.

n.a.

27

$-75$

n.a.

n.a.

220

n.a.

$-77$

$-67$

n.a.

111

$-100$

$-100$

n.a.

14

$-2$

$-9$

n.a.

n.a.

$-14$

n.a.

$-20$

$-57$

$-2$

$-53$

$-27$

n.a.

$-41$

$-42$

n.a.

$-46$

113

n.a.

131

n.a.

$-26$

$-32$

n.a.
-100

n.a.

n.a.

n.a.

n.a.

n.a.

64

$-79$

n.a.

100

n.a.

n.a.

$-46$

$-63$

$-25$

n.a.

n.a.

n.a.

n.a.

$-53$

$-100$

n.a.

n.a.

n.a.

n.a.

n.a.

$-82$

$-78$

n.a.

n.a.

n.a.

$-47$

n.a. 